\title{
Synthetic nitrogen coupled with seaweed extract and microbial inoculants improves rice (Oryza sativa L.) production under a dual cropping system
}

\author{
Huimin Xie, ${ }^{1}$ Ke Wu, ${ }^{1}$ Anas Iqbal, ${ }^{1}$ Izhar Ali, ${ }^{1}$ Liang He, ${ }^{1}$ Saif Ullah, ${ }^{1}$ Shangqin Wei, ${ }^{1}$ \\ Quan Zhao, ${ }^{1}$ Xiaoyan Wu, ${ }^{1}$ Qianying Huang, ${ }^{2}$ Ligeng Jiang ${ }^{1}$ \\ ${ }^{1}$ Key Laboratory of Crop Cultivation and Farming Systems College of Agriculture, Guangxi University; \\ ${ }^{2}$ Guangxi Subtropical Research Institute, Guangxi Province, Nanning, China
}

\section{Highlights}

- This study assessed the combined effect of seaweed extraction and microbial inoculants with reduced chemical fertilizer rates on the rice production.

- Seaweed extraction coupled with chemical fertilizer significantly improved biomass accumulation and grain yield of rice.

- Seaweed extraction and microbial inoculants, combined with a $20 \%$ reduction in nitrogen fertilizer, improved rice growth and yield.

- The correlation analysis revealed that the growth and yields traits significantly contributed to the higher grain yield.

- This study provides a sustainable nutrient management plan that increases crop production while minimizing costs of chemical $N$ fertilizer application.

\begin{abstract}
The over-reliance on synthetic nitrogen $(\mathrm{N})$ in current farming is a major concern because of its adverse effects on soil quality, the environment, and crop production. Organic fertilizers such as seaweed extract (SE) and microbial inoculants (MI) provide alternatives to chemical fertilizers that could decrease the amount of synthetic $\mathrm{N}$ needing to be applied and improve crop growth pro-
\end{abstract}

Correspondence: Ligeng Jiang, Key Laboratory of Crop Cultivation and Farming Systems College of Agriculture, Guangxi University, Nanning 530004, China. Tel.: +86.13768311375.

E-mail: jiang@gxu.edu.cn

Key words: Rice; seaweed; microbial inoculants; biomass accumulation; grain yield.

Acknowledgements: this research was financially supported by the National Key Research and Development Project of China (2018YFD020030503). We thank all of our collaborators from the agricultural stations for help with conducting this experiment.

Contributions: $\mathrm{HX}, \mathrm{KW}, \mathrm{AI}$, contributed equally to this work.

Conflicts of interest: the authors declare no potential conflict of interest.

Received for publication: 3 January 2021.

Revision received: 9 February 2021.

Accepted for publication: 9 February 2021.

${ }^{C}$ Copyright: the Author(s), 2021

Licensee PAGEPress, Italy

Italian Journal of Agronomy 2021; 16:1800

doi:10.4081/ija.2021.1800

This article is distributed under the terms of the Creative Commons Attribution Noncommercial License (by-nc 4.0) which permits any noncommercial use, distribution, and reproduction in any medium, provided the original author(s) and source are credited. ductivity. This study evaluated the combined effect of SE and MI with reduced $\mathrm{N}$ rates on the growth, biomass accumulation, yield, and yield components of an N-efficient rice cultivar (Baixiang 139-A) and N-inefficient rice cultivar (Guiyu 9-B). Field experiments were conducted in the early and late growing seasons at different sites in Guangxi province, China, in 2019. A total of five treatments, such as $\mathrm{T}_{1}: \mathrm{N} 180+\mathrm{SE} 0+\mathrm{MI} 0\left(\mathrm{~kg} \mathrm{ha}^{-1}\right)$ (control); $\mathrm{T}_{2}: \mathrm{N} 180+\mathrm{SE} 3+\mathrm{MI} 3\left(\mathrm{~kg} \mathrm{ha}^{-1}\right) ; \mathrm{T}_{3}: \mathrm{N} 144+\mathrm{SE} 3+\mathrm{MI} 3(\mathrm{~kg}$ $\left.\mathrm{ha}^{-1}\right) ; \mathrm{T}_{4}: \mathrm{N} 126+\mathrm{SE} 3+\mathrm{MI} 3\left(\mathrm{~kg} \mathrm{ha}^{-1}\right)$; and $\mathrm{T}_{5}: \mathrm{N} 108+\mathrm{SE} 3+$ MI $3\left(\mathrm{~kg} \mathrm{ha}^{-1}\right)$ were used. The leaf area index (LAI), effective panicle number, grain per spike, grain filling rate, and 1000-grain weight were significantly increased in $T_{2}$ and $T_{3}$ compared with the control. The treatments $T_{2}$ and $T_{3}$ enhanced the biomass accumulation and grain yield of rice compared with the control. Furthermore, differences in the growth, yield, and yield components among the different cultivars were significant; however, there were no significant differences among the different locations. $\mathrm{T}_{3}$ increased the LAI, grain filling rate, biomass accumulation, and grain yield of rice by $4.5 \%, 5.9 \%, 6.6 \%$, and $5.2 \%$, respectively, compared with the control. Improvements in grain yield were mainly attributed to the enhanced growth and yield components. The correlation analysis also confirmed that LAI, productive tillers, grain filling rate, and biomass accumulation were positively correlated with grain yield. In sum, $\mathrm{T}_{3}[\mathrm{~N} 144+\mathrm{SE}$ $3+$ MI $\left.3\left(\mathrm{~kg} \mathrm{ha}^{-1}\right)\right]$ could achieve higher grain yield despite a reduction in the usage of chemical N. Generally, this study provides a sustainable nutrient management plan that increases crop production while minimizing costs of chemical $\mathrm{N}$ fertilizer application.

\section{Introduction}

Rice (Oryza sativa L.) provides staple food for more than $60 \%$ of China's population (Yuan, 2014). Approximately 30.18 million hectares of rice were cultivated in China in 2018, accounting for $26 \%$ of the grain cultivated area nationally, and a total of 21.12 
million tons of rice were produced (NBSC, 2018) China needs to produce 23,108 tons of rice by 2030 to meet the expected increase in per capita demand (Normile, 2008). Nitrogen (N) is important for plant growth, as $\mathrm{N}$ regulates crop yield by supporting the photosynthetic and sink properties of plants (Tubiello et al., 2015; Wang et al., 2016). The current farming system relies heavily on chemical $\mathrm{N}$ fertilizers to achieve higher yields. However, crop yield does not improve linearly with $\mathrm{N}$ fertilizer input (McGuire, 2015; Pathak et al., 2011), and extreme $\mathrm{N}$ fertilization poses major environmental concerns, such as increased greenhouse gas emissions, groundwater pollution, and soil quality deterioration (Mahajan et al., 2008; Cai et al., 2018). Furthermore, the longterm use of nitrogenous fertilizers has been shown to increase the acidification, deterioration, and compaction of arable soils, thus limiting plant growth and production (Yue et al., 2012; Guo et al., 2017). This continued dependency on chemical $\mathrm{N}$ fertilizer for agricultural crop production is not sustainable. There is thus, a need to implement sustainable management strategies that can feed the rising population and reduce environmental costs. The amount of $\mathrm{N}$ fertilization in China was estimated to be approximately 29.619 million tons, accounting for $21 \%$ of agricultural $\mathrm{N}$ applications globally (FAO, FAOSTAT, 2014). The average annual $\mathrm{N}$ fertilization rate is $180 \mathrm{~kg} / \mathrm{hm}^{2}$, which is $75 \%$ greater than the worldwide average annual $\mathrm{N}$ application rate for rice (Ma et al., 2008; Peng et al., 2009; Chen et al., 2014) and exceeds the $\mathrm{N}$ fertilizer input for high-yield paddy fields (Peng et al., 2006). China is a major consumer of $\mathrm{N}$ fertilizer, but the $\mathrm{N}$ utilization rate is not high (30-50\%) (Zhao and Sha, 2014). Moreover, more than $45 \%$ of $\mathrm{N}$ fertilizers are lost to the ecological environment (Ju and Zhang, 2003; Ligeng and Weixing, 2002).

There is a growing interest in improving N-use efficiency to reduce costs without compromising crop productivity. Currently, the most challenging issue is to enhance grain yield, to feed the population on a sustainable basis with the least cost to the environment(Mueller et al., 2012; Morone et al., 2019). Several N fertilizer management techniques have been used, including optimal $\mathrm{N}$ dosage (Chen et al., 2015), side-deep placement (Yao et al., 2018), and slow-release $\mathrm{N}$ fertilization (Yang et al., 2012). However, the implementation of these approaches has limitations because they are labour-intensive and lack of advanced technology (Anadon et al., 2016). In contrast to traditional synthetic $\mathrm{N}$ fertilization, organic fertilizers are considered effective and environmentally friendly alternative fertilizers to improve crop productivity and soil health (Nkoa, 2014; Iqbal et al., 2019; Iqbal, 2020a). Seaweed extract (SE) is a bio-organic fertilizer derived from large algae in the ocean (Ullah et al., 2008). In this context, SE biostimulants are a greener alternative towards sustainably increasing crop yields (Ghosh et al., 2015). Unlike the traditional organic inputs employed in rice production which usually result in increased environmental impacts, at least in the short term (Hokazono and Hayashi, 2012), these biostimulants are unique wherein stable yield improvements are observed when used along with conventional fertilizers. Furthermore, its contains several mineral components and biologically active substances that can benefit crops and soil (Adekiya et al., 2019; Rathore et al., 2009). Seaweed extract contains a variety of growth regulators, such as cytokinin, auxin, and gibberellin required for plant growth and development (Durand et al., 2003). Seaweed extract can be naturally degraded, is non-toxic, does not pollute the environment, and provides an innocuous alternative to chemical fertilizers, which can induce much harm when applied in excess (Dhargalkar and Pereira, 2005).

Microbial agents are natural products composed of beneficial microorganisms and active microbial strains (Alori and Babalola,
2018). They can stimulate microbial activity directly or indirectly and improve soil nutrient mobility (Suyal et al., 2016). They can be used as biological fertilizer in soil or plants and can promote plant growth, improve soil fertility, and enhance crop productivity (Jacoby et al., 2017). Microbial agents are products containing specific living microorganisms that can decompose organic and inorganic substances in the soil, activate soil nutrients, and enhance the ability of plants to absorb mineral nutrients (Muhammad et al., 2016). Application of MI can benefit the soil microbial composition and activity (Yu et al., 2010; Liu et al., 2015), may increase crop yield, improve soil chemical and physical properties including, the content and mineralization rate of soil organic matter, the contents of essential nutrients and the structure of soil aggregates (Zhang et al., 2005; Liu et al., 2015). Moreover, application of MI may offer an effective way for incorporation of large straw loads into cropping soils instead of burning, and has been increasingly adopted in recent years in China. The application of SE and microbial inoculants (MI) can promote an increase in rice biomass accumulation and rice production (Chen, 2017). Indeed, microbes are critical drivers of soil functions and agricultural crop productivity (Singh and Trivedi, 2017). One possible approach for reducing $\mathrm{N}$ input without compromising yield is to use a new green organic fertilizer as a supplementary fertilizer.

Rice leaf area index (LAI), dry matter accumulation (DMA), and panicle grain number are strongly associated with grain yield (Iqbal et al., 2019). The LAI is an important indicator reflecting leaf coverage and crop growth (Katsura et al., 2007). Some studies have suggested that increases in LAI are beneficial for increasing grain yield (Haboudane et al., 2004; Hu et al., 2019). DMA after the heading stage is also closely related to rice grain yield, and the yield is affected by the proportion of dry matter distributed to the ear and the amount of material transferred to the ear in the later stage (Tang et al., 2015; Haiming et al., 2018). Previous studies have focused on the effects of $\mathrm{N}$ application rate and fertilization timing on different rice cultivars. However, our understanding of how variation in $\mathrm{N}$ utilization efficiency affects the growth and biomass of different rice cultivars and its relationship to rice grain yield under combined organic and inorganic amendments is poor. Here, organic fertilizer combined with $\mathrm{N}$ fertilizer was hypothesized to improve soil functionality and thus increase leaf area, dry matter, and grain yield. The objectives of this study were twofold: i) to evaluate the joint effect of SE and MI with reduced $\mathrm{N}$ fertilizer on the growth, yield, and yield traits of different rice cultivars; and ii) to characterize the relationships between leaf physiological characteristics, biomass accumulation, and grain yield.

\section{Materials and methods}

\section{Experimental site and climatic conditions}

The experiment was conducted in Guangxi province, southern China at three different sites (i.e., Binyang County, Liucheng County, and Yulin City) during the early (March-July) and late seasons (August-November). Table 1 shows the soil chemical properties of the experimental sites. Soil samples were collected at the depth of 0-20 cm before the commencement experiment. The soil was air-dried and crushed for initial characterization of soil chemical properties. The soil is acidic in nature with a $\mathrm{pH}$ of 5.98, and having averaged soil organic carbon $19.35\left(\mathrm{~g} \mathrm{~kg}^{-1}\right)$, total nitrogen $2.0\left(\mathrm{~g} \mathrm{~kg}^{-1}\right)$, available phosphorous (188.78 $\left.\mathrm{mg} \mathrm{kg}^{-1}\right)$, and available potassium $140.66\left(\mathrm{mg} \mathrm{kg}^{-1}\right)$. 

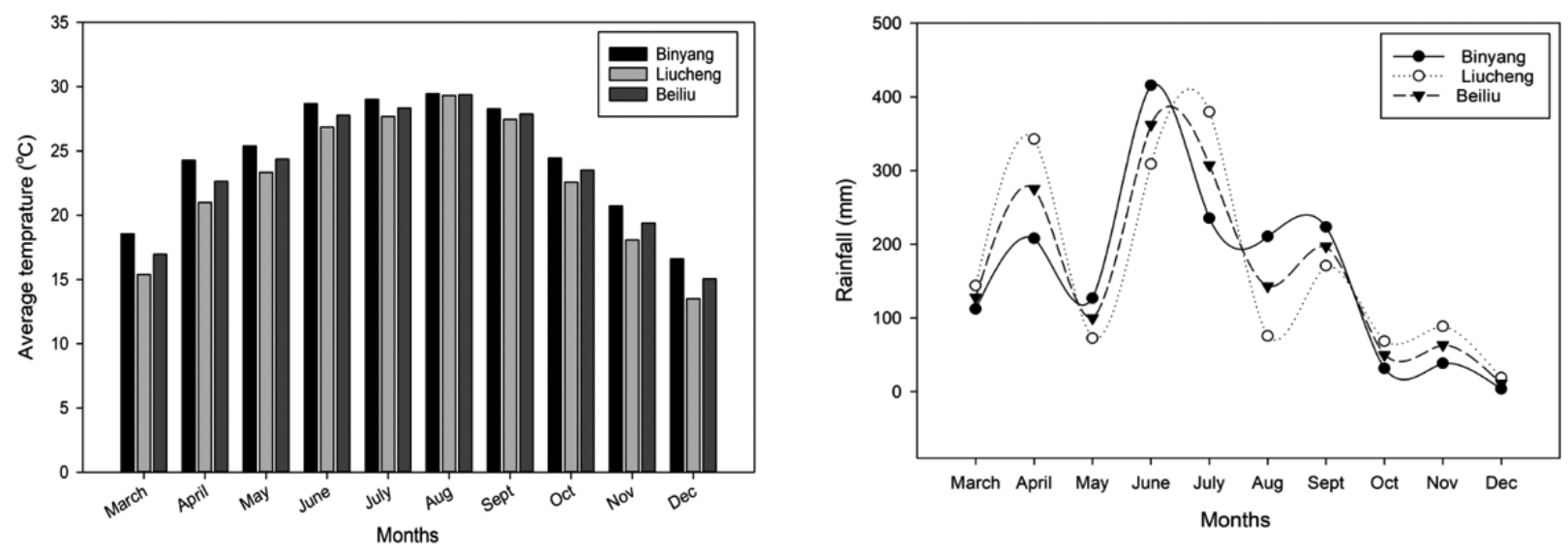

Figure 1. Average monthly temperature and precipitation ( $\mathrm{mm}$ ) of experimental sites (Binyang, Liucheng and Beiliu) during the early and late growing season. Note: Date collected from local weather monitoring station.

Table 1. Soil chemical properties before experimentation.

\begin{tabular}{lccccccc} 
Site & $\mathrm{pH}$ & $\mathrm{TN}(\mathrm{g} / \mathrm{kg})$ & SOC $(\mathrm{g} / \mathrm{kg})$ & AN $(\mathrm{mg} / \mathrm{kg})$ & & AP $(\mathrm{mg} / \mathrm{kg})$ & AK $(\mathrm{mg} / \mathrm{kg})$ \\
Binyang & 5.31 & 2.08 & 21.05 & 255.5 & 126.48 & 231 \\
Lincheng & 8.08 & 2.74 & 24.56 & 206.5 & 104.5 & 81 \\
\hline Yulin & 4.97 & 1.2 & 12.45 & 108.5 & 335.36 & 110 \\
\hline
\end{tabular}

TN, total nitrogen; SOC, soil organic carbon; AN, available nitrogen; AP, available phosphorous; AK, available potassium.

\section{Treatment structure and field management}

Field experiments were performed in a randomized complete block design with three replicates. The size of each plot was 20.2 $\mathrm{m}^{2}$. Seaweed extract (SE) and microbial inoculants (MI) were the organic sources of fertilizer, and urea was the chemical $\mathrm{N}$ fertilizer used in this study. SE and MI are commercial products provided by Qingdao Haida biological Group Co., Ltd. The main components of SE: $\mathrm{P}_{2} \mathrm{O}_{5}+\mathrm{K}_{2} 0>20 \%$, Organic matter $>20 \%$, seaweed polysaccharide $>15 \%$. Each bag of seaweed essence $500 \mathrm{~g}$. Furthermore, the microbial agent is a yellow fully soluble powder with an effective viable count of more than 20 billion/g. The study consisted of five treatments as reported in Table 2.

The recommended dose of phosphorous $\left(\mathrm{P}_{2} \mathrm{O}_{2}\right) 90\left(\mathrm{~kg} \mathrm{ha}^{-1}\right)$ and potassium $\left(\mathrm{K}_{2} \mathrm{O}\right) 180\left(\mathrm{~kg} \mathrm{ha}^{-1}\right)$ fertilizers were used in this study. Two different rice cultivars, Baixiang 139 (N efficient) and Guiyu 9 (N inefficient) were used as test crops. Initially, seeds were sown in the plastic trays; early rice was transplanted when seedlings were 25-days old, and late rice was transplanted when seedlings were 15 days old. Nitrogen (urea) and potassium fertilizers (KCL) were applied in three splits: $50 \%$ at transplanting, 30\% at the tillering stage, and $20 \%$ at the panicle initiation stage. In contrast, phosphate fertilizer $\left(\mathrm{P}_{2} \mathrm{O}_{2}\right), \mathrm{SE}$, and $\mathrm{MI}$ were applied as a basal fertilizer one day before seedling transplantation. Normal standing water was provided at a depth of four $\mathrm{cm}$ from transplantation to physiological maturity. All other agronomic practices (i.e., irrigation, pesticides and insecticides) were conducted in the same manner for all treatments.
Table 2. Treatment combination.

\begin{tabular}{lccc} 
Treatment & Nitrogen $\left(\mathrm{kg} \mathrm{ha}^{-1}\right)$ & SE $\left(\mathrm{kg} \mathrm{ha}^{-1}\right)$ & MI $\left(\mathrm{kg} \mathrm{ha}^{-1}\right)$ \\
T1 (CK) & 180 & 0 & 0 \\
T2 & 180 & 3 & 3 \\
\hline T3 & 144 & 3 & 3 \\
T4 & 126 & 3 & 3 \\
\hline T5 & 108 & 3 & 3 \\
\hline
\end{tabular}

SE, seaweed extract; MI, microbial inoculants.

\section{Sampling and measurements}

To determine DMA and LAI, five rice plants were randomly collected from each treatment at the heading and maturity stages. Rice plants were then divided into three parts: stems, leaves, and spikes. For LAI determination, 5 leaves from each plant were randomly selected, and leaf length and width were measured with a ruler. LAI was calculated by the specific leaf weight method according to the method of Tiansheng et al. (2007). The rice samples were dried in an oven with starting temperature of $105^{\circ} \mathrm{C}$ for $30 \mathrm{~min}$ and continued the drying process at $85^{\circ} \mathrm{C}$ for $72 \mathrm{~h}$ for determination of DMA. After rice harvesting and threshing, the samples dried with sunlight until 14\% moisture content was achieved, measurements of grain yield were taken (Figure 1).

\section{Data analysis}

Analysis of variance was conducted to test the differences in growth, dry matter accumulatio, grain yield and yield attributes of 
rice using Statistics 8.1 analytical software. The collected data were first check for normal distribution and after following the assumptions. Data were analysed in a completely randomized design using one-way ANOVA. Microsoft Excel 2010 was used to organize the data, and data in percentages were arcsine-transformed to normalize the variables before analysis. Means were differentiated using the least significant difference tests at $\mathrm{P}<0.05$. Pearson's correlation analyses were conducted to evaluate the relationships between growth, yield, and yield components in Statistics 8.1 software.

\section{Results}

\section{Leaf area index}

Leaf area index was significantly affected by treatment, cultivar, and site during both seasons (Table 3 ). During the early season, the highest LAI $\left(3.45 \mathrm{~cm}^{2}\right)$ was observed in $\mathrm{T}_{3}$ of Baixiang 139 , whereas the lowest $\left(2.09 \mathrm{~cm}^{2}\right)$ LAI was observed in $T_{5}$ at Binyang site. During the late season, no significant differences in LAI $(\mathrm{P}<0.05)$ were observed at Binyang site. There were significant differences in the LAI of Baixiang 139 and Guiyu 9 under each fertilization treatment during the early season at Liucheng site. Baixiang 139 had the highest LAI $\left(2.78 \mathrm{~cm}^{2}\right)$ in $\mathrm{T}_{2}$.

There were no significant differences in the LAI of Baixiang 139 and Guiyu 9 under each fertilization treatment in the early season at Yulin. There were no significant differences in the LAI of Baixiang 139 under each fertilization treatment at Liucheng and Yulin sites. Furthermore, there were no significant differences $(\mathrm{P}<0.05)$ in the LAI during the late season under each treatment at Binyang site. However, the LAI of Baixiang 139 under each treatment was significantly different at Liucheng site. The Baixing 139, cultivar had the highest LAI $\left(2.72 \mathrm{~cm}^{2}\right)$ in $\mathrm{T}_{2}$, and the lowest LAI $\left(1.49 \mathrm{~cm}^{2}\right)$ was observed in $\mathrm{T}_{4}$. There were no significant differences in LAI across treatments at Yulin.

\section{Dry matter accumulation}

\section{Dry matter accumulation at the heading stage}

The combined application of SE and MI with reduced $\mathrm{N}$ rates significantly affected DMA at the heading stage at Liucheng in the early season; no significant differences were observed among the other test sites. There were no significant differences in the DMA of Baixiang 139 and Guiyu 9 under each fertilization treatment (Table 4). However, differences in DMA among the different sites for Baixiang 139 and Guiyu 9 were statistically $(\mathrm{P}<0.05)$ significant under each fertilization treatment (Table 3). Baixiang 139 produced the highest DMA $\left(6723 \mathrm{~kg} \mathrm{ha}^{-1}\right)$ under $\mathrm{T}_{2}$, and the lowest DMA $\left(5010 \mathrm{~kg} \mathrm{ha}^{-1}\right)$ was observed in $\mathrm{T}_{5}$. However, the DMA of $\mathrm{T}_{3}$ was not significantly different $(\mathrm{P}<0.05)$ from that of $\mathrm{T}_{2}$. Similarly, Guiyu 9 led to the highest DMA $\left(7786 \mathrm{~kg} \mathrm{ha}^{-1}\right)$ in $\mathrm{T}_{2}$ and the lowest DMA $\left(96086 \mathrm{~kg} \mathrm{ha}^{-1}\right)$ in $\mathrm{T}_{5}$. In addition, there were no significant differences in the DMA of Baixiang 139 and Guiyu 9 under each fertilization treatment at Yulin site and the other test sites.

\section{Dry matter accumulation at the maturity stage}

The co-application of SE and MI with reduced N rates significantly affected the DMA at the maturity stage at Liucheng site; however, no significant differences were observed among the other test sites. There were no significant differences in the DMA of Baixiang 139 and Guiyu 9 under each fertilization treatment (Table 4). The Nefficient cultivar Baixiang 139 resulted in the highest DMA $(11,196 \mathrm{~kg}$ $\mathrm{ha}^{-1}$ ) under $\mathrm{T}_{2}$. Similarly, the N-inefficient cultivar Guiyu 9 produced the highest DMA $\left(12,497 \mathrm{~kg} \mathrm{ha}^{-1}\right)$ in $\mathrm{T}_{2}$ and the lowest DMA $(10,248$ $\mathrm{kg} \mathrm{ha}^{-1}$ ) in $\mathrm{T}_{4}$. However, there were no significant differences in the DMA of Baixiang 139 and Guiyu 9 under each fertilization treatment at Yulin and Binyang sites. There were also no significant differences in the DMA of Baixiang 139 under each fertilization treatment at Liucheng site; however, there were substantial differences in the DMA of Guiyu No 9 at Liucheng. The DMA of Guiyu 9 was highest $\left(99,819 \mathrm{~kg} \mathrm{ha}^{-1}\right)$ in $\mathrm{T}_{2}$ and lowest $\left(8165 \mathrm{~kg} \mathrm{ha}^{-1}\right)$ in $\mathrm{T}_{4}$. There were no significant differences in the DMA of Baixiang 139 and Guiyu 9 under each fertilization treatment at Yulin site.

\section{Rice yield and yield components}

Rice yield and yield components (i.e., panicle number, grains per panicle, and grain yield) were significantly affected by $\mathrm{N}$ level coupled with $\mathrm{SE}$ and $\mathrm{MI}(\mathrm{P} \leq 0.05)$ (Table 5$)$. The productive panicle number of Baixiang 139 and Guiyu 9 at Liucheng significantly differed among treatments. However, there were no significant differences in the grain filling rate $(\%)$ and 1000-grain weight (g, TGW) among experimental sites and cultivars. The combined fertilization of SE and MI with lower N rates significantly increased rice grain yield at different sites (Table 5). During the early season, the rice grain yield of Baixiang 139 was $5.28 \%$ and $3.44 \%$ higher in $\mathrm{T}_{2}$ and $\mathrm{T}_{3}$, respectively, compared with the control. The rice grain yield of Guiyu 9 was $6.74 \%$ higher in $\mathrm{T}_{3}$ compared with the control. During the late season, the grain yield of Baixiang 139 was $2.19 \%$ and $1.04 \%$ higher in $\mathrm{T}_{2}$ and $\mathrm{T}_{3}$, respectively, compared with the control. The grain yield of Guiyu 9 was $1.91 \%$ and $1.35 \%$ high-

Table 3. Effect of combined seaweed and microbial inoculants on rice leaf area index.

\begin{tabular}{|c|c|c|c|c|c|c|c|c|c|}
\hline Cultivars & Trt & Binyang & $\begin{array}{c}\text { Early }\left(\mathrm{cm}^{2}\right) \\
\text { Liucheng }\end{array}$ & Yulin & Mean & Binvang & $\begin{array}{l}\text { Late }\left(\mathrm{cm}^{2}\right) \\
\text { Liucheng }\end{array}$ & Yulin & Mean \\
\hline Baixiang- 139 & $\begin{array}{l}\mathrm{T}_{1} \\
\mathrm{~T}_{2} \\
\mathrm{~T}_{3} \\
\mathrm{~T}_{4} \\
\mathrm{~T}_{5}\end{array}$ & $\begin{array}{c}3.45 \pm 0.79^{\mathrm{a}} \\
2.98 \pm 0.14^{\mathrm{ab}} \\
2.09 \pm 0.06^{\mathrm{b}} \\
2.79 \pm 0.54^{\mathrm{ab}} \\
2.90 \pm 1.03^{\mathrm{ab}}\end{array}$ & $\begin{array}{l}2.67 \pm 0.47^{\mathrm{a}} \\
2.78 \pm 0.27^{\mathrm{a}} \\
1.84 \pm 0.05^{\mathrm{c}} \\
2.27 \pm 0.33^{\mathrm{b}} \\
1.89 \pm 0.17^{\mathrm{bc}}\end{array}$ & $\begin{array}{l}2.94 \pm 0.26^{\mathrm{a}} \\
3.42 \pm 0.83^{\mathrm{a}} \\
2.67 \pm 0.28^{\mathrm{a}} \\
2.64 \pm 0.61^{\mathrm{a}} \\
2.25 \pm 0.83^{\mathrm{a}}\end{array}$ & $\begin{array}{l}3.02 \\
3.06 \\
2.20 \\
2.57 \\
2.35\end{array}$ & $\begin{array}{c}1.35 \pm 0.56^{\mathrm{a}} \\
1.36 \pm 0.03^{\mathrm{a}} \\
1.21 \pm 0.25^{\mathrm{a}} \\
1.18 \pm 0.39^{\mathrm{a}} \\
1.30 \pm 0.1^{\mathrm{a}}\end{array}$ & $\begin{array}{c}1.97 \pm 0.45^{\mathrm{bc}} \\
2.72 \pm 0.45^{\mathrm{a}} \\
2.17 \pm 0.43^{\mathrm{ab}} \\
1.49 \pm 0.16^{\mathrm{c}} \\
1.79 \pm 0.42^{\mathrm{bc}}\end{array}$ & $\begin{array}{l}2.55 \pm 0.17^{\mathrm{a}} \\
2.51 \pm 0.48^{\mathrm{a}} \\
2.28 \pm 0.38^{\mathrm{a}} \\
2.80 \pm 0.52^{\mathrm{a}} \\
2.63 \pm 0.37^{\mathrm{a}}\end{array}$ & $\begin{array}{l}1.96 \\
2.20 \\
1.89 \\
1.82 \\
1.91\end{array}$ \\
\hline Guiyu-9 & $\begin{array}{l}\mathrm{T}_{1} \\
\mathrm{~T}_{2} \\
\mathrm{~T}_{3} \\
\mathrm{~T}_{4} \\
\mathrm{~T}_{5}\end{array}$ & $\begin{array}{l}4.06 \pm 0.35^{\mathrm{a}} \\
4.48 \pm 0.43^{\mathrm{a}} \\
3.63 \pm 0.69^{\mathrm{a}} \\
3.89 \pm 0.56^{\mathrm{a}} \\
4.21 \pm 0.27^{\mathrm{a}}\end{array}$ & $\begin{array}{c}3.25 \pm 0.33^{\mathrm{a}} \\
3.04 \pm 0.05^{\mathrm{ab}} \\
2.51 \pm 0.48^{\mathrm{bc}} \\
2.48 \pm 0.44^{\mathrm{bc}} \\
1.99 \pm 0.08^{\mathrm{c}}\end{array}$ & $\begin{array}{l}4.04 \pm 1.03^{\mathrm{a}} \\
2.98 \pm 0.72^{\mathrm{a}} \\
3.91 \pm 0.88^{\mathrm{a}} \\
4.28 \pm 0.51^{\mathrm{a}} \\
3.03 \pm 0.66^{\mathrm{a}}\end{array}$ & $\begin{array}{l}3.78 \\
3.50 \\
3.35 \\
3.55 \\
3.08\end{array}$ & $\begin{array}{c}0.72 \pm 0.22^{\mathrm{a}} \\
0.90 \pm 0.13^{\mathrm{a}} \\
1.14 \pm 0.52^{\mathrm{a}} \\
0.91 \pm 0.15^{\mathrm{a}} \\
1.36 \pm 0.5^{\mathrm{a}}\end{array}$ & $\begin{array}{l}2.71 \pm 0.19^{\mathrm{a}} \\
2.85 \pm 0.63^{\mathrm{a}} \\
2.51 \pm 0.32^{\mathrm{a}} \\
2.18 \pm 0.38^{\mathrm{a}} \\
2.08 \pm 0.51^{\mathrm{a}}\end{array}$ & $\begin{array}{l}2.35 \pm 0.67^{\mathrm{a}} \\
2.38 \pm 0.73^{\mathrm{a}} \\
2.64 \pm 1.05^{\mathrm{a}} \\
2.07 \pm 0.67^{\mathrm{a}} \\
1.97 \pm 0.32^{\mathrm{a}}\end{array}$ & $\begin{array}{l}1.93 \\
2.04 \\
2.10 \\
1.72 \\
1.80\end{array}$ \\
\hline
\end{tabular}

$\mathrm{T}_{1}, \mathrm{~N} 180+\mathrm{SE} 0+\mathrm{MI0}\left(\mathrm{kg} \mathrm{ha}^{-1}\right) ; \mathrm{T}_{2}, \mathrm{~N} 180+\mathrm{SE} 3+\mathrm{MI} 3\left(\mathrm{~kg} \mathrm{ha}^{-1}\right) ; \mathrm{T}_{3}, \mathrm{~N} 144+\mathrm{SE} 3+\mathrm{MI} 3\left(\mathrm{~kg} \mathrm{ha}^{-1}\right) ; \mathrm{T}_{4}, \mathrm{~N} 126+$ S3kg ha + MI3 $\left(\mathrm{kg} \mathrm{ha}^{-1}\right) ; \mathrm{T}_{5}$, N108 + SE3 + MI3 (kg ha $\left.{ }^{-1}\right)$. SE, seaweed extract; MI, microbial inoculants; Trt, Treatment. a-cValues followed by the same letters within column are not significantly different at $\mathrm{P}<0.05$. 
er in $T_{2}$ and $T_{3}$, respectively, compared with the control. However, there were no significant differences in grain yield among the different sites. Table 5 shows that the average grain yield of the early and late seasons at the three test sites was significantly affected by fertilization treatment. The grain yield of Baixiang 139 was $3.75 \%$, and $2.25 \%$ higher in $\mathrm{T}_{2}$ and $\mathrm{T}_{3}$, respectively, compared with the control. The grain yield of Guiyu 9 was $1.34 \%$ and $4.28 \%$ higher in $\mathrm{T}_{2}$ and $\mathrm{T}_{3}$, respectively, compared with the control.

Table 4. Effect of combined seaweed and microbial inoculants on rice dry matter accumulation.

\begin{tabular}{|c|c|c|c|c|c|c|c|c|c|c|}
\hline \multirow[t]{2}{*}{ Cultivars } & & \multirow[t]{2}{*}{ Trt } & \multicolumn{3}{|c|}{ Early season $\left(\mathrm{kg} \mathrm{ha}^{-1}\right)$} & \multirow[t]{2}{*}{ Mean } & \multicolumn{3}{|c|}{ Late season $\left(\mathrm{kg} \mathrm{ha}^{-1}\right)$} & \multirow[t]{2}{*}{ Mean } \\
\hline & & & Binyang & Liucheng & Yulin & & Binyang & Liucheng & YuLin & \\
\hline \multirow[t]{10}{*}{ Heading stage } & \multirow[t]{5}{*}{ Baixiang 139} & $\mathrm{~T}_{1}$ & $5407 \pm 915^{\mathrm{a}}$ & $6213 \pm 132^{a b}$ & $7348 \pm 163^{\mathrm{a}}$ & 6323 & $6778 \pm 583^{\mathrm{a}}$ & $8249 \pm 209^{a}$ & $7484 \pm 1139^{a}$ & 7504 \\
\hline & & $\mathrm{T}_{2}$ & $6115 \pm 574^{\mathrm{a}}$ & $6724 \pm 867^{a}$ & $6869 \pm 77^{\mathrm{ab}}$ & 6570 & $6577 \pm 135^{\mathrm{a}}$ & $8440 \pm 300^{a}$ & $7149 \pm 1257^{a}$ & 7389 \\
\hline & & $\mathrm{T}_{3}$ & $5615 \pm 1018^{a}$ & $5801 \pm 1067^{a b}$ & $6497 \pm 516^{b}$ & 5971 & $6290 \pm 1812^{a}$ & $8430 \pm 536^{\mathrm{a}}$ & $6678 \pm 236^{\mathrm{a}}$ & 7132 \\
\hline & & $\mathrm{T}_{4}$ & $5849 \pm 1201^{a}$ & $5270 \pm 774^{\mathrm{ab}}$ & $6307 \pm 606^{\mathrm{b}}$ & 5809 & $5862 \pm 586^{\mathrm{a}}$ & $8595 \pm 1063^{\mathrm{a}}$ & $7480 \pm 416^{a}$ & 7312 \\
\hline & & $\mathrm{T}_{5}$ & $5103 \pm 1166^{a}$ & $5011 \pm 649^{b}$ & $7121 \pm 643^{a b}$ & 5745 & $6185 \pm 36^{\mathrm{a}}$ & $8709 \pm 224^{a}$ & $6959 \pm 877^{a}$ & 7284 \\
\hline & \multirow[t]{5}{*}{ Guiyu 9} & $\mathrm{~T}_{1}$ & $7498 \pm 498^{a}$ & $7664 \pm 670^{\mathrm{ab}}$ & $8968 \pm 960^{a}$ & 8043 & $5742 \pm 899^{a}$ & $9156 \pm 1315^{\mathrm{ab}}$ & $7490 \pm 1158^{a}$ & 7463 \\
\hline & & $\mathrm{T}_{2}$ & $7956 \pm 205^{\mathrm{a}}$ & $7786 \pm 532^{\mathrm{a}}$ & $9939 \pm 708^{a}$ & 8560 & $6365 \pm 802^{\mathrm{a}}$ & $9819 \pm 841^{\mathrm{a}}$ & $7520 \pm 1238^{a}$ & 7901 \\
\hline & & $\mathrm{T}_{3}$ & $7331 \pm 1224^{a}$ & $6743 \pm 112^{b c}$ & $9944 \pm 669^{a}$ & 8006 & $7436 \pm 1714^{a}$ & $8978 \pm 503^{a b}$ & $6829 \pm 808^{a}$ & 7747 \\
\hline & & $\mathrm{T}_{4}$ & $6600 \pm 1492^{\mathrm{a}}$ & $6104 \pm 472^{c}$ & $9659 \pm 1671^{a}$ & 7454 & $6549 \pm 1899^{a}$ & $8165 \pm 648^{b}$ & $7301 \pm 545^{\mathrm{a}}$ & 7339 \\
\hline & & $\mathrm{T}_{5}$ & $6433 \pm 609^{a}$ & $6087 \pm 411^{\mathrm{c}}$ & $8456 \pm 122^{\mathrm{a}}$ & 6992 & $6115 \pm 1387^{a}$ & $8279 \pm 432^{\mathrm{ab}}$ & $7321 \pm 232^{a}$ & 7238 \\
\hline \multirow[t]{10}{*}{ Maturity stage } & \multirow[t]{5}{*}{ Baixiang 139} & $\mathrm{~T}_{1}$ & $9589 \pm 1182^{a}$ & $9864 \pm 478^{a b}$ & $11762 \pm 1424^{a b}$ & 10405 & $8004 \pm 2280^{a}$ & $10229 \pm 1631^{\mathrm{a}}$ & $10387 \pm 771^{a}$ & 9540 \\
\hline & & $\mathrm{T}_{2}$ & $11006 \pm 2822^{a}$ & $11196 \pm 1263^{a}$ & $14050 \pm 2281^{a}$ & 12084 & $8254 \pm 894^{a}$ & $12080 \pm 1899^{a}$ & $10847 \pm 1002^{a}$ & 10393 \\
\hline & & $\mathrm{T}_{3}$ & $8218 \pm 416^{a}$ & $9766 \pm 904^{\mathrm{ab}}$ & $11314 \pm 729^{b}$ & 9766 & $8654 \pm 2752^{a}$ & $10285 \pm 740^{a}$ & $10570 \pm 487^{a}$ & 9836 \\
\hline & & $\mathrm{T}_{4}$ & $8182 \pm 1823^{a}$ & $9327 \pm 536^{b}$ & $10377 \pm 61^{\mathrm{b}}$ & 9295 & $7530 \pm 1411^{a}$ & $10077 \pm 481^{a}$ & $10607 \pm 1846^{a}$ & 9405 \\
\hline & & $\mathrm{T}_{5}$ & $8596 \pm 2314^{a}$ & $9466 \pm 177^{\mathrm{b}}$ & $10313 \pm 1363^{b}$ & 9458 & $8467 \pm 380^{a}$ & $10737 \pm 1426^{a}$ & $10531 \pm 1383^{a}$ & 9916 \\
\hline & \multirow[t]{5}{*}{ Guiyu 9} & $\mathrm{~T}_{1}$ & $11003 \pm 591^{\mathrm{a}}$ & $13284 \pm 905^{\mathrm{a}}$ & $11317 \pm 126^{a}$ & 11868 & $7186 \pm 385^{\mathrm{a}}$ & $11365 \pm 394^{a}$ & $10015 \pm 2972^{a}$ & 9522 \\
\hline & & $\mathrm{T}_{2}$ & $12929 \pm 1965^{a}$ & $12497 \pm 689^{a}$ & $12942 \pm 1497^{a}$ & 12790 & $6136 \pm 194^{\mathrm{a}}$ & $11748 \pm 917^{a}$ & $9788 \pm 1005^{a}$ & 9224 \\
\hline & & $\mathrm{T}_{3}$ & $11304 \pm 2839^{a}$ & $11599 \pm 1373^{a b}$ & $16146 \pm 5820^{a}$ & 13016 & $7797 \pm 1672^{a}$ & $11946 \pm 737^{a}$ & $9649 \pm 1571^{a}$ & 9797 \\
\hline & & $\mathrm{T}_{4}$ & $11660 \pm 1213^{a}$ & $10249 \pm 1035^{b}$ & $14851 \pm 2206^{a}$ & 12253 & $6375 \pm 417^{a}$ & $10390 \pm 1245^{\mathrm{a}}$ & $8765 \pm 254^{a}$ & 8510 \\
\hline & & $\mathrm{T}_{5}$ & $12389 \pm 1364^{a}$ & $10420 \pm 603^{b}$ & $11854 \pm 1532^{a}$ & 11554 & $7354 \pm 832^{\mathrm{a}}$ & $10871 \pm 858^{a}$ & $9129 \pm 912^{a}$ & 9118 \\
\hline
\end{tabular}

a-c Values followed by the same letters within column are not significantly different at $\mathrm{P}<0.05$.

Table 5. Effect of combined seaweed and microbial inoculants on early rice plant productive tillers, grain per panicle, filled grain rate, grain weight and grain yield.

\begin{tabular}{|c|c|c|c|c|c|c|c|}
\hline Site & Cultivars & Treatment & PF (10 $/$ ha) & GP & FGR\% & 1000-GW (g) & GY $\left(\mathrm{kg} \mathrm{ha}^{-1}\right)$ \\
\hline Binyang & $\begin{array}{l}\text { Baixiang } 139 \\
\text { Guiyu } 9\end{array}$ & $\begin{array}{l}\mathrm{T}_{1} \\
\mathrm{~T}_{2} \\
\mathrm{~T}_{3} \\
\mathrm{~T}_{4} \\
\mathrm{~T}_{5} \\
\mathrm{~T}_{1} \\
\mathrm{~T}_{2} \\
\mathrm{~T}_{3} \\
\mathrm{~T}_{4} \\
\mathrm{~T}_{5}\end{array}$ & $\begin{array}{c}306 \pm 34^{\mathrm{a}} \\
338 \pm 59^{\mathrm{a}} \\
313 \pm 39^{\mathrm{a}} \\
213 \pm 41^{\mathrm{b}} \\
256 \pm 34^{\mathrm{ab}} \\
283 \pm 27^{\mathrm{a}} \\
292 \pm 21^{\mathrm{a}} \\
251 \pm 63^{\mathrm{a}} \\
289 \pm 44^{\mathrm{a}} \\
268 \pm 12^{\mathrm{a}}\end{array}$ & $\begin{array}{c}120 \pm 2.5^{\mathrm{ab}} \\
117 \pm 8.3^{\mathrm{ab}} \\
102 \pm 1.5^{\mathrm{b}} \\
147 \pm 43^{\mathrm{a}} \\
118 \pm 15^{\mathrm{ab}} \\
110 \pm 1^{\mathrm{b}} \\
119 \pm 10^{\mathrm{ab}} \\
131 \pm 6.1^{\mathrm{a}} \\
114 \pm 8.2^{\mathrm{ab}} \\
119 \pm 16^{\mathrm{ab}}\end{array}$ & $\begin{array}{l}77.78 \pm 7.3^{\mathrm{a}} \\
84.27 \pm 4.8^{\mathrm{a}} \\
80.56 \pm 7.5^{\mathrm{a}} \\
82.55 \pm 4.5^{\mathrm{a}} \\
85.91 \pm 1.7^{\mathrm{a}} \\
68.84 \pm 1.2^{\mathrm{b}} \\
73.85 \pm 1.4^{\mathrm{a}} \\
70.45 \pm 3.5^{\mathrm{ab}} \\
69.84 \pm 3.1^{\mathrm{ab}} \\
72.48 \pm 2.0^{\mathrm{ab}}\end{array}$ & $\begin{array}{c}18.07 \pm 0.43^{\mathrm{a}} \\
18.16 \pm 0.41^{\mathrm{a}} \\
18.31 \pm 0.46^{\mathrm{a}} \\
18.31 \pm 0.5^{\mathrm{a}} \\
17.82 \pm 0.53^{\mathrm{a}} \\
22.46 \pm 0.38^{\mathrm{a}} \\
22.52 \pm 1.03^{\mathrm{a}} \\
22.84 \pm 0.7^{\mathrm{a}} \\
22.56 \pm 0.23^{\mathrm{a}} \\
22.81 \pm 0.55^{\mathrm{a}}\end{array}$ & $\begin{array}{c}4737 \pm 331.48^{a b} \\
5255 \pm 173^{\mathrm{a}} \\
4881 \pm 546^{\mathrm{ab}} \\
4284 \pm 589^{\mathrm{b}} \\
4516 \pm 412^{\mathrm{ab}} \\
4691 \pm 256^{\mathrm{b}} \\
5077 \pm 144^{\mathrm{ab}} \\
5542 \pm 817^{\mathrm{a}} \\
4782 \pm 231^{\mathrm{ab}} \\
4673 \pm 315^{\mathrm{b}}\end{array}$ \\
\hline Liucheng & Baixiang 139 & $\begin{array}{l}\mathrm{T}_{1} \\
\mathrm{~T}_{2} \\
\mathrm{~T}_{3} \\
\mathrm{~T}_{4} \\
\mathrm{~T}_{5} \\
\mathrm{~T}_{1} \\
\mathrm{~T}_{2} \\
\mathrm{~T}_{3} \\
\mathrm{~T}_{4} \\
\mathrm{~T}_{5}\end{array}$ & $\begin{array}{c}257 \pm 16^{\mathrm{a}} \\
281 \pm 25^{\mathrm{a}} \\
246 \pm 29^{\mathrm{a}} \\
254 \pm 19^{\mathrm{a}} \\
237 \pm 3^{\mathrm{a}} \\
240 \pm 5^{\mathrm{a}} \\
233 \pm 17^{\mathrm{a}} \\
224 \pm 13^{\mathrm{ab}} \\
206 \pm 7^{\mathrm{bc}} \\
198 \pm 15^{\mathrm{c}}\end{array}$ & $\begin{array}{l}133 \pm 17^{\mathrm{a}} \\
142 \pm 17^{\mathrm{a}} \\
131 \pm 22^{\mathrm{a}} \\
138 \pm 4.6^{\mathrm{a}} \\
148 \pm 12^{\mathrm{a}} \\
184 \pm 3.7^{\mathrm{a}} \\
179 \pm 24^{\mathrm{a}} \\
161 \pm 34^{\mathrm{a}} \\
160 \pm 5.9^{\mathrm{a}} \\
175 \pm 3.7^{\mathrm{a}}\end{array}$ & $\begin{array}{c}70.21 \pm 7.4^{\mathrm{a}} \\
76.85 \pm 6.5^{\mathrm{a}} \\
74.39 \pm 3.2^{\mathrm{a}} \\
76.58 \pm 2.9^{\mathrm{a}} \\
67.38 \pm 13.2^{\mathrm{a}} \\
59.76 \pm 5.4^{\mathrm{a}} \\
61.14 \pm 3.7^{\mathrm{a}} \\
65.57 \pm 7.3^{\mathrm{a}} \\
66.75 \pm 2.5^{\mathrm{a}} \\
63.12 \pm 6.0^{\mathrm{a}}\end{array}$ & $\begin{array}{l}17.72 \pm 0.43^{a} \\
17.77 \pm 0.28^{a} \\
17.31 \pm 0.12^{a} \\
17.33 \pm 0.16^{a} \\
17.31 \pm 0.14^{a} \\
20.55 \pm 0.26^{a} \\
20.25 \pm 1.29^{a} \\
21.17 \pm 0.78^{a} \\
21.19 \pm 0.67^{a} \\
20.74 \pm 0.25^{a}\end{array}$ & $\begin{array}{c}5088 \pm 138^{a} \\
5362 \pm 123^{a} \\
5179 \pm 116^{a} \\
5098 \pm 200^{a} \\
4681 \pm 296^{b} \\
5637 \pm 116^{a} \\
5403 \pm 81^{a b} \\
5535 \pm 336^{a b} \\
5149 \pm 247^{b c} \\
4894 \pm 116^{c}\end{array}$ \\
\hline Yulin & Baixiang 139 & $\begin{array}{l}\mathrm{T}_{1} \\
\mathrm{~T}_{2} \\
\mathrm{~T}_{3} \\
\mathrm{~T}_{4} \\
\mathrm{~T}_{5} \\
\mathrm{~T}_{1} \\
\mathrm{~T}_{2} \\
\mathrm{~T}_{3} \\
\mathrm{~T}_{4} \\
\mathrm{~T}_{5}\end{array}$ & $\begin{array}{c}404 \pm 42^{\mathrm{a}} \\
399 \pm 32^{\mathrm{a}} \\
349 \pm 53^{\mathrm{a}} \\
375 \pm 20^{\mathrm{a}} \\
367 \pm 37^{\mathrm{a}} \\
295 \pm 18^{\mathrm{a}} \\
293 \pm 41^{\mathrm{a}} \\
330 \pm 31^{\mathrm{a}} \\
327 \pm 9^{\mathrm{a}} \\
277 \pm 44^{\mathrm{a}}\end{array}$ & $\begin{array}{l}104 \pm 8.2^{\mathrm{a}} \\
120 \pm 4.8^{\mathrm{a}} \\
120 \pm 17^{\mathrm{a}} \\
112 \pm 14^{\mathrm{a}} \\
113 \pm 11^{\mathrm{a}} \\
109 \pm 5.9^{\mathrm{a}} \\
130 \pm 47^{\mathrm{a}} \\
138 \pm 49^{\mathrm{a}} \\
125 \pm 28^{\mathrm{a}} \\
113 \pm 17^{\mathrm{a}}\end{array}$ & $\begin{array}{l}77.56 \pm 6.5^{\mathrm{a}} \\
80.28 \pm 1.8^{\mathrm{a}} \\
74.72 \pm 1.7^{\mathrm{a}} \\
71.89 \pm 14^{\mathrm{a}} \\
77.96 \pm 1.2^{\mathrm{a}} \\
43.54 \pm 6.5^{\mathrm{a}} \\
58.95 \pm 1.0^{\mathrm{a}} \\
54.63 \pm 2.0^{\mathrm{a}} \\
54.29 \pm 1.2^{\mathrm{a}} \\
49.71 \pm 15^{\mathrm{a}}\end{array}$ & $\begin{array}{c}17.59 \pm 0.53^{\mathrm{a}} \\
17.72 \pm 0.14^{\mathrm{a}} \\
17.49 \pm 0.2^{\mathrm{a}} \\
18.02 \pm 0.83^{\mathrm{a}} \\
17.68 \pm 0.42^{\mathrm{a}} \\
21.43 \pm 0.43^{\mathrm{a}} \\
21.09 \pm 1.67^{\mathrm{a}} \\
21.67 \pm 0.51^{\mathrm{a}} \\
22.05 \pm 0.76^{\mathrm{a}} \\
22.25 \pm 0.16^{\mathrm{a}}\end{array}$ & $\begin{array}{c}5320 \pm 745^{\mathrm{b}} \\
6269 \pm 304^{\mathrm{a}} \\
5641 \pm 271^{\mathrm{ab}} \\
5471 \pm 268^{\mathrm{ab}} \\
5220 \pm 385^{\mathrm{b}} \\
4768 \pm 494^{\mathrm{a}} \\
4746 \pm 229^{\mathrm{a}} \\
5035 \pm 479^{\mathrm{a}} \\
5006 \pm 343^{\mathrm{a}} \\
4950 \pm 271^{\mathrm{a}}\end{array}$ \\
\hline
\end{tabular}

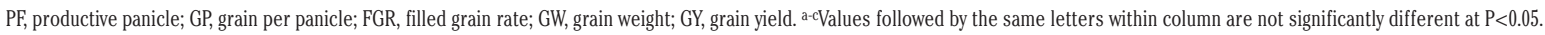




\section{The effect of different nitrogen levels on actual rice yield}

There were no significant differences in actual yield among the various fertilization treatments. During the early season, the actual yield of Baixiang 139 was $5.28 \%$ and $3.44 \%$ higher in $\mathrm{T}_{2}$ and $\mathrm{T}_{3}$, respectively, compared with the control (Table 5). Similarly, the actual yield of Guiyu 9 was $6.74 \%$ and $0.86 \%$ higher in $\mathrm{T}_{3}$ and $\mathrm{T}_{2}$, respectively, compared with the control. The actual yield of Guiyu 9 was $1.91 \%$ and $1.35 \%$ higher in $\mathrm{T}_{2}$ and $\mathrm{T}_{3}$, respectively, compared with the control. However, across both seasons, $\mathrm{T}_{2}$ increased the grain yield by $2.57 \%$ compared with the control.

\section{Correlation analysis between rice agronomic traits and actual yield under different nitrogen levels}

The correlation analysis of the relevant indicators under the combined fertilization is shown in Tables 6 and 7. The correlation analysis revealed that the LAI, DMA, effective spike, total grains per spike, and grain filling rate were positively correlated with the grain yield of rice. This analysis showed that increases in growth and yield components significantly contributed to the higher grain yield of rice.

Table 6. Effect of combined seaweed and microbial inoculants on late rice plant productive tillers, grain per panicle, filled grain rate, grain weight and grain yield.

\begin{tabular}{|c|c|c|c|c|c|c|c|}
\hline Site & Cultivars & Treatment & PF (104/ha) & GP & FGR\% & 1000-GW (g) & GY (kg ha-1) \\
\hline Binyang & 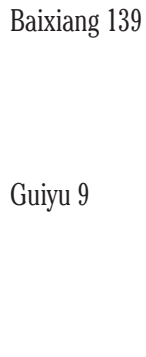 & $\begin{array}{l}\mathrm{T}_{1} \\
\mathrm{~T}_{2} \\
\mathrm{~T}_{3} \\
\mathrm{~T}_{4} \\
\mathrm{~T}_{5} \\
\mathrm{~T}_{1} \\
\mathrm{~T}_{2} \\
\mathrm{~T}_{3} \\
\mathrm{~T}_{4} \\
\mathrm{~T}_{5}\end{array}$ & $\begin{array}{c}293 \pm 95^{\mathrm{a}} \\
273 \pm 52^{\mathrm{a}} \\
276 \pm 74^{\mathrm{a}} \\
269 \pm 59^{\mathrm{a}} \\
300 \pm 23^{\mathrm{a}} \\
153 \pm 11^{\mathrm{a}} \\
133 \pm 16^{\mathrm{a}} \\
136 \pm 88^{\mathrm{a}} \\
138 \pm 25^{\mathrm{a}} \\
137 \pm 36^{\mathrm{a}}\end{array}$ & $\begin{array}{l}105 \pm 7.1^{\mathrm{a}} \\
108 \pm 9.2^{\mathrm{a}} \\
112 \pm 2.2^{\mathrm{a}} \\
111 \pm 4.3^{\mathrm{a}} \\
112 \pm 10^{\mathrm{a}} \\
149 \pm 8.9^{\mathrm{a}} \\
135 \pm 35^{\mathrm{a}} \\
165 \pm 14^{\mathrm{a}} \\
149 \pm 17^{\mathrm{a}} \\
198 \pm 70^{\mathrm{a}}\end{array}$ & $\begin{array}{l}58.14 \pm 5.9^{\mathrm{a}} \\
64.18 \pm 4.3^{\mathrm{a}} \\
61.10 \pm 2.5^{\mathrm{a}} \\
64.82 \pm 10^{\mathrm{a}} \\
60.60 \pm 3.8^{\mathrm{a}} \\
53.91 \pm 9.8^{\mathrm{a}} \\
56.60 \pm 13^{\mathrm{a}} \\
50.42 \pm 5.8^{\mathrm{a}} \\
51.64 \pm 4.9^{\mathrm{a}} \\
55.10 \pm 6.4^{\mathrm{a}}\end{array}$ & $\begin{array}{c}19.09 \pm 1.6^{\mathrm{a}} \\
18.20 \pm 1.09^{\mathrm{a}} \\
19.05 \pm 0.93^{\mathrm{a}} \\
18.31 \pm 0.2^{\mathrm{a}} \\
18.12 \pm 0.7^{\mathrm{a}} \\
22.05 \pm 1.12^{\mathrm{a}} \\
22.53 \pm 2.67^{\mathrm{a}} \\
23.08 \pm 0.69^{\mathrm{a}} \\
22.66 \pm 0.72^{\mathrm{a}} \\
22.09 \pm 1.35^{\mathrm{a}}\end{array}$ & $\begin{array}{l}3449 \pm 646^{\mathrm{a}} \\
3215 \pm 559^{\mathrm{a}} \\
3592 \pm 249^{\mathrm{a}} \\
3215 \pm 538^{\mathrm{a}} \\
2829 \pm 187^{\mathrm{a}} \\
2483 \pm 474^{\mathrm{a}} \\
2564 \pm 500^{\mathrm{a}} \\
2584 \pm 336^{\mathrm{a}} \\
2350 \pm 294^{\mathrm{a}} \\
2422 \pm 708^{\mathrm{a}}\end{array}$ \\
\hline Liucheng & Baixiang 139 & $\begin{array}{l}\mathrm{T}_{1} \\
\mathrm{~T}_{2} \\
\mathrm{~T}_{3} \\
\mathrm{~T}_{4} \\
\mathrm{~T}_{5} \\
\mathrm{~T}_{1} \\
\mathrm{~T}_{2} \\
\mathrm{~T}_{3} \\
\mathrm{~T}_{4} \\
\mathrm{~T}_{5}\end{array}$ & $\begin{array}{l}290 \pm 22^{\mathrm{b}} \\
335 \pm 15^{\mathrm{a}} \\
289 \pm 16^{\mathrm{b}} \\
265 \pm 22^{\mathrm{b}} \\
280 \pm 16^{\mathrm{b}} \\
215 \pm 19^{\mathrm{b}} \\
254 \pm 28^{\mathrm{a}} \\
214 \pm 12^{\mathrm{b}} \\
209 \pm 13^{\mathrm{b}} \\
209 \pm 4.8^{\mathrm{b}}\end{array}$ & $\begin{array}{c}151 \pm 25^{\mathrm{a}} \\
155 \pm 27^{\mathrm{a}} \\
139 \pm 19^{\mathrm{a}} \\
181 \pm 39^{\mathrm{a}} \\
161 \pm 12^{\mathrm{a}} \\
159 \pm 96^{\mathrm{ab}} \\
153 \pm 19^{\mathrm{b}} \\
194 \pm 21^{\mathrm{a}} \\
159 \pm 30^{\mathrm{ab}} \\
167 \pm 11^{\mathrm{ab}}\end{array}$ & $\begin{array}{c}48.70 \pm 1.6^{\mathrm{a}} \\
53.50 \pm 5.7^{\mathrm{a}} \\
56.46 \pm 11.5^{\mathrm{a}} \\
51.12 \pm 8.7^{\mathrm{a}} \\
55.34 \pm 4.6^{\mathrm{a}} \\
53.16 \pm 3.0^{\mathrm{a}} \\
52.11 \pm 3.3^{\mathrm{a}} \\
52.82 \pm 3.7^{\mathrm{a}} \\
50.50 \pm 4.4^{\mathrm{a}} \\
53.62 \pm 2.2^{\mathrm{a}}\end{array}$ & $\begin{array}{c}19.62 \pm 0.45^{\mathrm{a}} \\
18.86 \pm 1.12^{\mathrm{a}} \\
19.24 \pm 0.14^{\mathrm{a}} \\
18.80 \pm 1.06^{\mathrm{a}} \\
19.15 \pm 0.58^{\mathrm{a}} \\
22.61 \pm 0.79^{\mathrm{ab}} \\
21.87 \pm 0.72^{\mathrm{b}} \\
22.48 \pm 0.26^{\mathrm{ab}} \\
23.13 \pm 0.55^{\mathrm{a}} \\
22.88 \pm 0.25^{\mathrm{ab}}\end{array}$ & $\begin{array}{c}5482 \pm 544^{\mathrm{a}} \\
5659 \pm 106^{\mathrm{a}} \\
5534 \pm 403^{\mathrm{a}} \\
5129 \pm 74^{\mathrm{a}} \\
5271 \pm 400^{\mathrm{a}} \\
5415 \pm 755^{\mathrm{a}} \\
5364 \pm 107^{\mathrm{a}} \\
5374 \pm 217^{\mathrm{a}} \\
5016 \pm 663^{\mathrm{a}} \\
4861 \pm 222^{\mathrm{a}}\end{array}$ \\
\hline Yulin & Baixiang 139 & $\begin{array}{l}\mathrm{T}_{1} \\
\mathrm{~T}_{2} \\
\mathrm{~T}_{3} \\
\mathrm{~T} 4 \\
\mathrm{~T}_{5} \\
\mathrm{~T}_{1} \\
\mathrm{~T}_{2} \\
\mathrm{~T}_{3} \\
\mathrm{~T}_{4} \\
\mathrm{~T}_{5}\end{array}$ & $\begin{array}{c}263 \pm 15^{\mathrm{a}} \\
269 \pm 48^{\mathrm{a}} \\
250 \pm 33^{\mathrm{a}} \\
257 \pm 29^{\mathrm{a}} \\
247 \pm 6.7^{\mathrm{a}} \\
176 \pm 16^{\mathrm{a}} \\
182 \pm 22^{\mathrm{a}} \\
186 \pm 26^{\mathrm{a}} \\
164 \pm 5^{\mathrm{a}} \\
166 \pm 7.5^{\mathrm{a}}\end{array}$ & $\begin{array}{c}156 \pm 41^{\mathrm{a}} \\
139 \pm 16^{\mathrm{a}} \\
128 \pm 12^{\mathrm{a}} \\
144 \pm 15^{\mathrm{a}} \\
142 \pm 27^{\mathrm{a}} \\
180 \pm 71^{\mathrm{a}} \\
168 \pm 19^{\mathrm{a}} \\
160 \pm 25^{\mathrm{a}} \\
169 \pm 4^{\mathrm{a}} \\
165 \pm 21^{\mathrm{a}}\end{array}$ & $\begin{array}{l}74.74 \pm 9.9^{\mathrm{a}} \\
71.88 \pm 0.5^{\mathrm{a}} \\
74.70 \pm 4.5^{\mathrm{a}} \\
71.22 \pm 4.8^{\mathrm{a}} \\
74.82 \pm 6.8^{\mathrm{a}} \\
58.37 \pm 2.5^{\mathrm{a}} \\
55.10 \pm 2.3^{\mathrm{a}} \\
63.73 \pm 7.6^{\mathrm{a}} \\
64.76 \pm 12^{\mathrm{a}} \\
65.11 \pm 8.5^{\mathrm{a}}\end{array}$ & $\begin{array}{l}19.02 \pm 0.36^{\mathrm{a}} \\
19.08 \pm 0.36^{\mathrm{a}} \\
18.75 \pm 0.68^{\mathrm{a}} \\
18.42 \pm 0.34^{\mathrm{a}} \\
19.13 \pm 0.47^{\mathrm{a}} \\
23.23 \pm 1.43^{\mathrm{a}} \\
24.05 \pm 0.91^{\mathrm{a}} \\
23.17 \pm 0.24^{\mathrm{a}} \\
22.40 \pm 0.35^{\mathrm{a}} \\
23.51 \pm 1.27^{\mathrm{a}}\end{array}$ & $\begin{array}{c}5343 \pm 249^{\mathrm{a}} \\
5712 \pm 739^{\mathrm{a}} \\
5297 \pm 457^{\mathrm{a}} \\
5103 \pm 518^{\mathrm{a}} \\
4799 \pm 269^{\mathrm{a}} \\
4790 \pm 385^{\mathrm{a}} \\
5002 \pm 419^{\mathrm{a}} \\
4900 \pm 96^{\mathrm{a}} \\
4827 \pm 304^{\mathrm{a}} \\
4780 \pm 488^{\mathrm{a}}\end{array}$ \\
\hline
\end{tabular}

$\mathrm{PF}$, productive panicle; GP, grain per panicle; FGR, filled grain rate; GW, grain weight; GY, grain yield. a,bValues followed by the same letters within column are not significantly different at $\mathrm{P}<0.05$.

Table 7. Correlation analysis between grain yield and yield components of rice.

\begin{tabular}{lcccccc} 
Index & LAI & GY & DM & PT & FGR & \\
LAI & 1 & & & & \\
GY & $0.69^{*}$ & & & & \\
\hline DM & $0.62^{*}$ & $0.79 *$ & & & \\
PT & $0.74^{*}$ & 0.48 & $0.73^{*}$ & & & \\
\hline GP & -0.37 & 0.19 & 0.05 & -0.57 & & \\
FGR & $0.60^{*}$ & 0.23 & -0.08 & 0.17 & -0.39 & \\
\hline TGW & -0.28 & -0.19 & -0.14 & -0.31 & 0.08 & -0.3 \\
\hline
\end{tabular}

LAI, leaf area index; GY, grain yield; DM, dry matter; PT, productive tillers; GP, grain per spike; TGW, 1000-grain weight; FGR, filled grain rate. * $\mathrm{P}=0.05$. 


\section{Discussion}

The appropriate use of $\mathrm{N}$ fertilizer is key for meeting the demand of the growing human population for food and soil for improving soil health and cereals crop quality (Iqbal et al., 2020b; Izhar et al., 2020; Ullah et al., 2020). However, the overuse of chemical $\mathrm{N}$ fertilizer can lead to several problems, such as environmental pollution, soil degradation, water contamination, and decreased crop productivity (Peng et al., 2015; Cai et al., 2018). Bio-organic fertilizers such as SE and MI provide viable alternatives to chemical fertilizer, as they do not have the negative effects of synthetic fertilizer and can promote sustainable agricultural production (Babalola and Glick, 2012). The goal of this study was to assess whether sustainable improvements in rice growth and production could be achieved by reducing the amount of synthetic $\mathrm{N}$ fertilizer applied and adding organic fertilizer, such as SE and MI).

The combined fertilization of $\mathrm{N}$ with $\mathrm{SE}$ and $\mathrm{MI}$ at two rates $\left[\mathrm{N} 180+\mathrm{SE} 3+\mathrm{MI} 3\left(\mathrm{~kg} \mathrm{ha}^{-1}\right)\right]$ and [N $\left.144+\mathrm{SE} 3+\mathrm{MI} 3\left(\mathrm{~kg} \mathrm{ha}^{-1}\right)\right]$ significantly increased the LAI, DMA, productive panicle number, grains per panicle, grain filling rate, TGW, and grain yield of rice compared with the control. The increases in growth, yield, and yield components were attributed to the combined fertilization of synthetic and bio-organic fertilizers in this study. These findings can be explained by the fact that SE and MI improve soil health and quality, which enhances plant nutrient uptake and thereby increases plant growth and biomass accumulation (Ullah et al., 2008; Jacoby et al., 2017). Furthermore, increases in growth and yield traits under combined treatments might stem from the presence of several cytokinin enzymes, including trans-zeatin riboside and their dihydro derivatives, which improve plant growth and health (Begum et al., 2018). The bioactive compounds in Ascophyllum nodosum extract and its organic subfractions have been shown to affect legume-rhizobia signalling mechanisms and result in more functional nodules and overall improvements in the growth of plants (Khan et al., 2013). Consistent with our findings, the application of SE has been shown to enhance early plant development and lead to increases in yield components in legume plants, including $12-25 \%$ higher grain yield, compared with the control (Sethi and Adhikary, 2008).

Another study found that the yield of the bean was improved by $25 \%$ using a foliar spray of SE (Haider et al., 2012). Sarhan et al. (2011) reported that SE can have positive effects on the growth and development of potatoes, and significantly improve the yield and quality of potatoes. The application of SE can also improve the amount of micronutrients in rice grains, such as $\mathrm{Cu}$ and $\mathrm{Zn}$, by up to $10 \%$ and $\mathrm{Fe}$ and $\mathrm{Mn}$ by up to $5 \%$ (Layek et al., 2014). SE contains chelating compounds, such as mannitol, that can increase the accessibility of some micronutrients to plants (Shah et al., 2013). Similar findings have also been made in wheat and okra (Zodape et al., 2009; Shah et al., 2013). The spraying of SE at 30 and 60day intervals after planting has been shown to maximize tuber yield, enhance $\mathrm{N}$ uptake, and increase protein content in potatoes (Haider et al., 2012).

In our study, increases in grain yield under the co-inoculation of SE and MI could stem from its positive effects on root proliferation and the uptake of N, P, and sulphur (S), which are required for protein synthesis (Shah et al., 2013). In addition, MI also improve plant growth by encouraging root development and altering root architecture through the processing of phytohormones, such as indole-3-acetic acid (Alori et al., 2017), which leads to increases in the number of root tips, surface area, and root length (Gamalero et al., 2002; Vacheron et al., 2013). Such root stimula- tion can help protect plants from pathogens and may also be linked to the induction of systemic tolerance (Ramirez and Maiti, 2016). These improvements in root morphological and physiological traits enhance root nutrient uptake capacity, which in turn increases $\mathrm{N}$ use efficiency, DMA, and grain yield (Yang et al., 2009; Izhar et al., 2020). A previous study found that Pseudomonas fluorescens had a positive effect on the growth of mung bean (Vigna radiata) plants in vitro and in situ by promoting increases in the root $(30 \%$ and $20 \%)$ and shoot length (20\% and $24 \%)$ through the P solubilization associated with acid production, which led to a decrease in pH (Katiyar and Goel, 2003). Botelho et al. (2015) reported a similar finding: the BR-5 strain of P. fluorescens stimulated the growth of maize in natural soil. MI increases plant growth and crop yield as well as a host plant nutrient. Other researchers, such as Arthur et al. (2003) and Zodape et al. (2008) have noted a substantial increase in the grain yield of crops stemming from the combined use of SE and MI. Furthermore, SE foliar spray could provide a promising alternative for improving yields under rainfed soybean production, as SE has been found to substantially enhance the oil content, oil yield, K, N, and raw sunflower seed proteins (Rathore et al., 2009; Osman and Salem, 2011).

\section{Conclusions}

Leaf area index, biomass accumulation, productive grains per panicle, grain filling rate, 1000-grains weight, and grain yield of rice were increased under the combined application of nitrogen fertilizer with seaweed extraction and microbial inoculants compared with the sole application of chemical fertilizer. Data from the three different experimental sites showed that the rice cultivars Baixiang 139 and Guiyu 9 can maintain higher growth yield and yield traits under the co-application treatment [N $144+$ SE $3+$ MI $\left.3\left(\mathrm{~kg} \mathrm{ha}^{-1}\right)\right]$. Furthermore, the correlation analysis revealed that the increases in the growth and yield traits significantly contributed to the higher grain yield of rice. Thus, the combined use of seaweed extraction and microbial inoculants with chemical fertilizer application improved the growth and yield of rice despite a $20 \%$ reduction in the application of synthetic nitrogen fertilizer.

\section{References}

Adekiya A, Agbede T, Aboyeji C, Dunsin O, Simeon V, 2019. Effects of biochar and poultry manure on soil characteristics and the yield of radish. Sci. Hortic. 243:457-63.

Alori ET, Babalola OO, 2018. Microbial inoculants for improving crop quality and human health in Africa. Front. Microbiol. 9:2213.

Alori ET, Glick BR, Babalola OO, 2017. Microbial phosphorus solubilization and its potential for use in sustainable agriculture. Front. Microbiol. 8:971.

Anadon LD, Chan G, Harley AG, Matus K, Moon S, Murthy SL, Clark WC, 2016. Making technological innovation work for sustainable development. Proc. Natl. Acad. Sci. U. S. A. 113:9682-90.

Arthur GD, Stirk WA, Van SJ, 2003. Effect of a seaweed concentrate on the growth and yield of three varieties of Capsicum annuum. South Afr. J. Bot. 69:207-11.

Babalola OO, Glick BR, 2012. The use of microbial inoculants in African agriculture: current practice and future prospects. J. 
Food Agric. Environ. 10:540-9.

Cai A, Zhang W, Xu M, Wang B, Wen S, Shah S, 2018. Soil fertility and crop yield after manure addition to acidic soils in South China. Nutr. Cycl. Agroecosyst. 111:61-72.

Chen BY, 2017. Seaweed essence and microbial agents on rice growth and yield of influence and the application prospect of analysis. MA thesis; Guangxi University, China.

Chen X, Cui Z, Fan M, Vitousek P, Zhao M, Ma W, Wang Z, Zhang W, Yan X, Yang J, Deng X, Gao Q, Zhang Q, Guo S, Ren J, Li S, Ye Y, Wang Z, Huang J, Tang Q, 2014. Producing more grain with lower environmental costs. Nature. 514:486-91.

Chen Y, Peng J, Wang J, Fu P, Hou Y, Zhang C, Fahad S, Peng S, Cui K, Nie L, 2015. Crop management based on multi-split topdressing enhances grain yield and nitrogen use efficiency in irrigated rice in China. Field Crop. Res. 184:50-7.

Dhargalkar VK, Pereira N, 2005. Seaweed: promising plant of the millennium. Natl. Inst. Oceanogr. 71:60-6.

Durand N, Brian X, Meyer C, 2003. The effect of marine bioactive substances (N PRO) and edogenouscytokinins on nitrate reductase activity in Arabidopsis thaliana. Physiol. Plant. 119:489-93.

FAO, FAOSTAT, 2014. Food and Agriculture Organization statistics. Food and Agriculture Organization of the United Nations, Rome, Italy. Available from: http://faostat.fao.org/default.aspx

Gamalero E, Martinotti MG, Trotta A, 2002. Morphogenetic modifications induced by Pseudomonas fluorescens A6RI and Glomus mosseae BEG12 in the root system of tomato differ according to plant growth conditions. N. Phytol. 155:293-300.

Ghosh A, Vijay Anand KG, Seth A, 2015. Life cycle impact assessment of seaweed based biostimulant production from onshore cultivated Kappaphycus alvarezii (Doty) Doty ex Silvadis it environmentally sustainable? Algal Res. 12:513e521.

Guo J, Hu X, Gao L, Xie K, Ling N, Shen Q, 2017. The rice production practices of high yield and high nitrogen use efficiency in Jiangsu, China. Sci. Rep. 7:1-10.

Haboudane D, Miller JR, Pattey E, 2004. Hyperspectral vegetation indices and novel algorithms for predicting green LAI of crop canopies: Modeling and validation in the context of precision agriculture. Remote Sens. Environ. 90:337-52.

Haider W, Chaudhary MA, Muhammad AP, Habat UA, Abdul M, Syed AR, Irfan A, 2012. Impact of foliar application of seaweed extract on growth, yield and quality of potato (Solanum tuberosum L.). Soil Environ. 31:157-62.

Haiming T, Xiaoping X, Chao L, Kaikai C, Ke W, Gen S, Fan F, Xiaochen P, 2018. Effects of different long-term fertilization managements on nutrition accumulation and translocation of rice plant in double cropping paddy field. Ecol. Environ Sci. 27:469-77.

Hokazono S, Hayashi K, 2012. Variability in environmental impacts during conversion from conventional to organic farming: a comparison among three rice production systems in Japan. J. Clean. Prod. 28:101e112.

Hu L, Qingxia Z, Chonghua Z, Zeng K, Chengzi W, Shangming W, 2019. Changes in leaf area index of early-season cropping rice and its relationship with yield under climate warming in Nanchang County. Ecol. Environ. Sci. 28:1785-92. Available from: http://www.jeesci.com

Iqbal A, He L, Ali I, Ullah S, Khan A, Khan A, Akhtar K, Wei S, Zhao Q, Zhang J, Jiang L, 2020a. Manure combined with chemical fertilizer increases rice productivity by improving soil health, post-anthesis biomass yield, and nitrogen metabolism. PLoS One. 7;15:e0238934.

Iqbal A, Liang H, Aziz K, Shangqin W, Kashif A, Izhar A, Saif U,
Fazal M, Quan Z, Ligeng J, 2019. Organic manure coupled with inorganic fertilizer: An approach for the sustainable production of rice by improving soil properties and nitrogen use efficiency. Agronomy. 9:651.

Iqbal A, Xie H, He L, Ahmad S, Hussain I, Raza H, Khan A, 2020b. Partial substitution of organic nitrogen with synthetic nitrogen enhances rice yield, grain starch metabolism and related genes expression under the dual cropping system. Saudi J. Biol. Sci. [Epub ahead of print].

Izhar A, Liang H, Saif U, Zhao Q, Shangqing W, Iqbal A, Fazal M, Tariq S, Ying X, Yuqiong L, Tianyuan L, Ligeng J, 2020. Biochar addition coupled with nitrogen fertilization impacts on soil quality, crop productivity, and nitrogen uptake under double-cropping system. Food Energy Security. 9(3). [Epub ahead of print].

Jacoby R, Peukert M, Succurro A, Koprivova A, Kopriva S, 2017. The role of soil microorganisms in plant mineral nutrition-current knowledge and future directions. Front. Plant Sci. 8:1617.

$\mathrm{Ju}$ XT, Zhang FS, 2003. Thinking about nitrogen recovery rate. Ecol. Environ. 12:192-7. Available from: http://www.eco-environment.com

Katiyar V, Goel R, 2003. Solubilization of inorganic phosphate and plant growth promotion by cold tolerant mutants of Pseudo monas fluorescens. Microbiol. Res. 158:163-8.

Katsura K, Maeda S, Horie T, Shiraiwa T, 2007. Analysis of yield attributes and crop physiological traits of Liangyoupeijiu, a hybrid rice recently bred in China. Field Crops Res. 103:1707.

Khan W, Palanisamy R, Critchley AT, Smith DL, Papadopoulos Y, Prithiviraj B, 2013. Ascophyllum nodosum extract and its organic fractions stimulate Rhizobium root nodulation and growth of Medicago sativa (Alfalfa). Commun. Soil Sci. Plant Anal. 44:900-8.

Layek J, Ramkrushna GI, Das A, Ghosh A, Krishnappa R, Panwar AS, Azad NS, Ngachan SV, Zodape ST, Buragohain J, Mawlong B, 2014. Seaweed sap as organic iostimulant for rice and maize production. Research bulletin no. 82. ICAR Research Complex for NEH region, Umiam, Meghalaya, India.

Ligeng J, Weixing C, 2002. Physiological mechanism and approaches for efficient nitrogen utilization in rice. Chinese J. Rice Sci. 03:64-7.

Liu G, Yu H, Ma J, Xu H, Wu Q, Yang J, Zhuang Y, 2015. Effects of straw incorporation along with microbial inoculant on methane and nitrous oxide emissions from rice fields. Sci. Total Environ. 518:209-16.

Ma W, Li J, Ma L, Wang F, Sisák I, Cushman G, Zhang F, 2008. Nitrogen flow and use efficiency in production and utilization of wheat, rice, and maize in China. Agric. Syst. 99:53-63.

Mahajan A, Bhagat R, Gupta R, 2008. Integrated nutrient management in sustainable rice-wheat cropping system for food security in India. AARC J. Agric. 6:29-32.

McGuire S, 2015. FAO, IFAD, and WFP. The state of food insecurity in the world 2015: meeting the 2015 international hunger targets: taking stock of uneven progress. Food and Agriculture Organization, Rome, Italy, pp. 623-624.

Morone P, Falcone PM, Lopolito A, 2019. How to promote a new and sustainable food consumption model: a fuzzy cognitive map study. J. Clean. Prod. 208:563-74.

Mueller ND, Gerber JS, Johnston M, Ray DK, Ramankutty N, Foley JA, 2012. Closing yield gaps through nutrient and water management. Nature. 490:254-7.

Muhammad IR, Liyakat HM, 2016. Bacteria and fungi can con- 
tribute to nutrients bioavailability and aggregate formation in degraded soils. Microbiol. Res. 26-41.

NBSC (National Bureau of Statistics of China), 2018. Chinese statistics. Available from: http://data.stats.gov.cn/ easyquery.htm

Nkoa R, 2014. Agricultural benefits and environmental risks of soil fertilization with anaerobic digestates: a review. Agron. Sustain. Develop. 34:473-92.

Normile D, 2008. Reinventing rice to feed the world. Science. 321:330-33.

Osman HE, Salem OM, 2011. Effect of seaweed extracts as foliar spray on sunflower yield and oil content. Egypt. J. Phycol. 12:60.

Pathak R, Lochab S, Raghuram N, 2011. Plant systems: improving plant nitrogen-use efficiency. In: M. Moo-Young (Ed.), Comprehensive biotechnology. Elsevier, Amsterdam, The Netherlands, pp. 209-218.

Peng S, Buresh RJ, Huang JL, Yang JC, Zou YB, Zhong XH, Wang GH, Zhang FS, 2006. Strategies for overcoming low agronomic nitrogen use efficiency in irrigated rice systems in China. Field Crop Res. 96:37-47.

Peng S, Tang Q, Zou Y, 2009. Current status and challenges of rice production in China. Plant Prod. Sci. 12:3-8.

Peng X, Yang Y, Yu C, Chen L, Zhang M, Liu Z, Sun Y, Luo S, Liu $\mathrm{Y}, 2015$. Crop management for increasing rice yield and nitrogen use efficiency in northeast China. Agron. J. 107:1682-90.

Ramirez JIS, Maiti RK, 2016. Research trends in abiotic stress resistance of crop. Springer Nature Singapore. 131-64.

Rathore SS, Chaudhary DR, Boricha GN, Ghosh A, Bhatt BP, Zodape ST, Patolia JS, 2009. Effect of seaweed extract on the growth, yield and nutrient uptake of Soybean (Glycine max) under rainfed conditions. South Afr. J. Bot. 75:351-5.

Sarhan TZ, 2011. Effect of humic acid and seaweed extracts on growth and yield of potato plant (Solanum tubersum L.) Desire cv. Mesopotamia J. Agric. 39:19-27.

Sethi SK, Adhikary SP, 2008. Effect of seaweed liquid fertilizer on vegetative growth and yield of black gram, brinjal and tomato. Seaweed Res. Utiln. 30:241-8.

Shah MT, Zodape ST, Chaudhary DR, Eswaran K, Chikara J, 2013. Seaweed sap as an alternative liquid fertilizer for yield and quality improvement of wheat. J. Plant Nutr. 36:192-200.

Singh BK, Trivedi P, 2017. Microbiome and the future for food and nutrient security. Microb. Biotechnol. 10:50-3.

Suyal DC, Soni R, Sai S, Goel R, 2016. Microbial inoculants as biofertilizer. In: D.P. Singh (Ed.), Microbial inoculants in sustainable agricultural productivity. Springer India, New Delhi, India, pp. 311-318.

Tang HM, Cheng AW, Xu YL, Guo LJ, Li WY, Xiao XP, Tang WG, Sun JM, 2015. Effects of long-term mixed application of organic and inorganic fertilizers on dry matter accumulation and yield of rice in double cropping rice fields. Res. Agric. Modern. 36:1091-8.

Tiansheng H, Xiping W, Wangxi P, Li Z, Shaowen Z, 2007. Advance in ground-based LAI measurement methods. J. Huazhong Agric. Univ. 02:270-5.

Tubiello FN, Salvatore M, Ferrara AF, House J, Federici S, Rossi S, 2015. The contribution of agriculture, forestry and other land use activities to global warming. Global Change Biol. 21:2655-60.

Ullah MS, Islam MS, Islam MA, Haque T, 2008. Effects of organic manures and chemical fertilizers on the yield of brinjal and soil properties. J. Bangladesh Agric. Univ. 6:271-6.

Ullah S, He L, Izhar A, Quan Z, Anas I, Shanqing W, Tariq S, Bo Y, Ligeng J, 2020. Biochar coupled with contrasting nitrogen sources mediated changes in carbon and nitrogen pools, microbial and enzymatic activity in paddy soil. J. Saudi Chem. Soc. 24:835-49.

Vacheron J, Desbrosses G, Bouffaud ML, 2013. Plant growth-promoting rhizobacteria and root system functioning. Front Plant. Sci. 4:356.

Wang Y, Feng G, Zhang T, Rutjyy Y, Gao Q, 2016. Effects of mixed application of controlled-release $\mathrm{N}$ fertilizer and common urea on grain yield, $\mathrm{N}$ uptake and soil $\mathrm{N}$ balance in continuous spring maize production. Sci. Agric. Sinica. 49:518-28.

Yang Y, Zhang M, Li Y, Fan X, Geng Y, 2012. Controlled release urea improved nitrogen use efficiency, activities of leaf enzymes, and rice yield. Soil Sci. Soc. Am. J. 76:2307-17.

Yao Y, Zhang M, Tian Y, Zhao M, Zhang B, Zeng K, Zhao M, Yin B, 2018. Urea deep placement in combination with Azolla for reducing nitrogen loss and improving fertilizer nitrogen recovery in rice field. Field Crop Res. 218:141-9.

Yu J, Chang Z, Huang H, Ye X, Ma Y, Qian Y, 2010. Effect of microbial inoculants for straw decomposing on soil microorganisms and the nutrients. J. Agro-Environ. Sci. 29:563-70.

Yuan LP, 2014. Development of hybrid rice to ensure food security. Rice Sci. 22:1-2.

Yue S, Meng Q, Zhao R, Ye Y, Zhang F, Cui Z, 2012. Change in nitrogen requirement with increasing grain yield for winter wheat. Agron. J. 104:1687-93.

Zhao HW, Sha HJ, 2014. Recent research of fertilizer-nitrogen use efficiency in paddy flied of China. J. Northeast Agric. Uni. 45:116-22.

Zodape ST, Kawarkhe VJ, Patolia JS, Warade AD, 2008. Effect of liquid seaweed fertilizer on yield and quality of okra (Abelmoschus esculentus L.). J. Sci. Industr. Res. 67:1115-7.

Zodape ST, Mukherjee S, Reddy MP, Chaudhary DR, 2009. Effect of Kappaphycus alvarezii (Doty) Doty ex silva. extract on grain quality, yield and some yield components of wheat (Triticum aestivum L.). Int. J. Plant Prod. 3:97-101. 